\title{
Medida de las principales propiedades en el estado fresco, y de la resistencia a la segregación, en un hormigón autocompactante de alta densidad fabricado con barita
}

\section{Measurement of properties and of the resistance to segregation in heavyweight, self-compacting barite concrete}

\author{
D. Revuelta $(*)$, A. Barona(*), D. Navarro(*)
}

Recepción/Received: 28-IX-07

Aceptación/Accepted: 21-VII-08

Publicado online/Online publishing: 22-VII-09

\section{RESUMEN}

El hormigón de alta densidad se emplea en estructuras en las que se necesita protección frente a radiaciones. El empleo de superplastificantes permite obtener mezclas trabajables con bajas relaciones agua/cemento y alta densidad. Este trabajo muestra los resultados obtenidos con el empleo de un superplastificante basado en policarboxilatos en un hormigón pesado de barita, que condujo a la obtención de un hormigón autocompactante. Las propiedades en el estado fresco se caracterizaron mediante ensayos adecuados para el hormigón autocompactante. Puesto que la segregación puede ser un aspecto clave en este tipo de hormigón, por las grandes diferencias entre las densidades de los componentes, se diseñó un ensayo específico para comprobar la homogeneidad del mismo. Los resultados permitieron comprobar que el hormigón fabricado poseía propiedades de autocompactabilidad, puesto que poseía la fluidez, la capacidad de paso a través de armaduras y la resistencia a la segregación adecuadas.

Palabras clave: trabajabilidad, hormigón fresco, superplastificante, estabilidad, hormigón autocompactante pesado.

\section{SUMMARY}

Heavyweight concrete is used for shielding in structures requiring protection against radiation. The addition of superplasticizers to mixes yields workable, high density materials with low water/cement ratios. This paper discusses the results of adding a polycarboxylate-based superplasticizer to heavyweight barite concrete to obtain a self-compacting mix. The fresh properties were characterized with trials suitable for self-compacting concrete. Since the large differences in constituent densities make segregation a key issue in this type of concrete, a specific trial was designed to check for homogeneity. The flowability, passing ability and resistance to segregation findings showed that the product obtained was a self-compacting concrete.

Keywords: workability, fresh concrete, superplasticizer, stability, heavyweight, self-compacting concrete.

(*) Instituto de Ciencias de la Construcción Eduardo Torroja (IETcc-CSIC) (Madrid, España). 


\section{INTRODUCCIÓN}

El hormigón pesado o de alta densidad se emplea como protección biológica frente a diferentes tipos de radiaciones ionizantes en centrales nucleares, unidades médicas y aceleradores de partículas. Se puede definir el hormigón pesado como aquel con una densidad mayor de 3.000 $\mathrm{kg} / \mathrm{m}^{3}$. Dos publicaciones del American Concrete Institute $(1,2)$ tratan los aspectos relativos a la fabricación de este tipo de material.

Aunque la composición química del hormigón tiene importancia cuando se trata de atenuar neutrones, en general la eficacia del apantallamiento es proporcional a la densidad del material por unidad de espesor de la pantalla. Por tanto, los métodos de diseño de mezclas tratan de obtener un hormigón de la mayor densidad posible sin comprometer la trabajabilidad de la mezcla. La tecnología de producción de hormigón pesado consiste en el uso de áridos de alta densidad como la limonita, magnetita, barita, o perdigones metálicos, entre otros.

La barita es un mineral natural, sulfato de bario $\left(\mathrm{BaSO}_{4}\right)$, que se encuentra en forma de vetas. Por lo general, la obtención de hormigones con una densidad mínima de $3.400 \mathrm{~kg} / \mathrm{m}^{3}$ se consigue con el empleo de baritas de una pureza superior al $90 \%$. La pureza del mineral determina su densidad, con rangos entre los 4.000 y los $4.300 \mathrm{~kg} / \mathrm{m}^{3}$ (3). Kilincarslan et al. (4) estudiaron la influencia de la cantidad de barita en la mezcla. Puesto que el agua es el más ligero de los componentes del hormigón, para obtener altas densidades es preferible el empleo de bajas relaciones agua/cemento. Topcu (5) demostró que, en hormigones baritados, relaciones agua/cemento en el rango de 0,34-0,60 resultan en hormigones con densidades entre los 3.200 y los $3.350 \mathrm{~kg} / \mathrm{m}^{3}$, y asientos medidos con el cono de Abrams entre 0,5 y $7 \mathrm{~cm}$. Las mezclas ensayadas no incorporaban ningún aditivo.

El hormigón autocompactante (HAC) se desarrolló en Japón a mediados de la década de los ochenta como un intento de mejorar la calidad de las estructuras de hormigón (6). Khatyat (7) define el HAC como un hormigón de alta fluidez, estable, que se extiende rápidamente y rellena los moldes y encofrados sin necesidad de compactación externa, y con una viscosidad lo suficientemente elevada para impedir la segregación. Por tanto, la diferencia entre el HAC y el hormigón convencional radica en el comportamiento en el estado fresco. Puesto que el HAC es una mezcla de alta fluidez y viscosidad comparado con el hormigón convencional, los métodos convencionales de caracterización de la trabajabilidad del hormigón no son aplicables (8), por lo que se han desarrollado nuevos procedimientos de ensayo. El hormigón autocompactante debe cumplir tres requerimientos principales: fluidez o habilidad de llenado, capacidad de paso a través de las armaduras y espacios confinados, y resistencia a la segregación o estabilidad. El ensayo de

\section{INTRODUCTION}

Heavyweight or high density concrete is used as a shield against ionizing radiation in nuclear plants, medical units and particle accelerator facilities. Heavyweight concrete can be defined as concrete with a density of over 3000 $\mathrm{kg} / \mathrm{m}^{3}$. Two American Concrete Institute $(1,2)$ publications deal with issues relative to the manufacture of this type of material.

Although the chemical composition of concrete is important for attenuating neutrons, in general the effectiveness of the shield is proportional to the density of the material per unit of screen thickness. Consequently, mix design methods attempt to obtain the highest density concrete possible without compromising mix workability. The technology involved in heavyweight concrete manufacture consists in using high density aggregate such as limonite, magnetite, barite or steel pellets, among others.

Barite is a natural mineral, barium sulfate $\left(\mathrm{BaSO}_{4}\right)$, found as veins in rock. As a rule, concrete densities of at least $3400 \mathrm{~kg} / \mathrm{m}^{3}$ can be attained when the barite aggregate used is over $90 \%$ pure, for the purity of the mineral determines its density, which ranges from 4000 to 4300 $\mathrm{kg} / \mathrm{m}^{3}$ (3). Kilincarslan et al. (4) studied the effect of the amount of barite in the mix. Since water is the least dense of the components in concrete, the lower the water/cement ratios, the higher the density. Topcu (5) showed that in barite-containing concrete, water/cement ratios in the range of 0.3-0.60 yield densities from 3200 to $3350 \mathrm{~kg} / \mathrm{m}^{3}$, and mean slumps of from 0.5 to $0.7 \mathrm{~cm}$. The mixes tested contained no admixtures.

Self-compacting concrete (SCC) was developed in Japan in the mid-nineteen eighties in an attempt to improve the quality of concrete structures (6). Khatyat (7) defines SCC as a stable, highly fluid concrete that spreads rapidly and fills moulds and forms with no need for additional consolidation, and with sufficient viscosity to prevent segregation. Consequently, the difference between SCC and conventional concrete lies in the behaviour of the fresh material. Since SCC is much more fluid and viscous than conventional concrete, conventional methods for characterizing concrete workability are not applicable (8). New test procedures have therefore been developed. Self-compacting concrete should meet three chief requirements: flowability, passing ability around reinforcement bars and in tight places, and resistance to segregation or stability. The slump (8-10), "V" funnel (8, $9,11)$ and $L-b o x(8,9)$ tests are three of the new methods proposed to characterize flowability and/or passing ability. 
escurrimiento (8-10), el embudo en $\mathrm{V}(8,9,11)$ y la caja en $\mathrm{L}(8,9)$ son tres de los nuevos métodos propuestos para la caracterización de la fluidez y/o la habilidad de paso. El ensayo de escurrimiento consiste en rellenar el cono de Abrams de una sola vez y sin ningún tipo de vibrado. Tras retirar el molde, se mide el tiempo que tarda el hormigón en alcanzar un diámetro de $500 \mathrm{~mm}, \mathrm{~T}_{50}$. Una vez que cesa el movimiento, se mide el diámetro final alcanzado por el hormigón, $d_{f}$. El ensayo con el embudo en $V$ registra el tiempo, $T_{V}$, consumido por el hormigón en vaciar un embudo con forma de V. La caja en L consiste en hacer fluir una columna de hormigón a través de un obstáculo de barras hacia una caja rectangular. Una vez que cesa el movimiento, se miden las alturas de la masa de hormigón en ambos extremos de la caja, y se define un coeficiente de bloqueo, $\mathrm{C}_{\mathrm{bL}}$, como la relación entre ambas alturas. Diversos países, entre ellos España, han aceptado ya estos métodos como Normas estándar (12-14).

Se han propuesto numerosos ensayos para la determinación de la resistencia a la segregación. La mayoría de ellos se basan en la caracterización del asentamiento experimentado por el árido grueso en columnas de hormigón en el estado fresco (15-19). Desafortunadamente, los resultados de repetibilidad y reproducibilidad hasta la fecha no son lo suficientemente amplios como para promover la normalización de estos métodos (15).

Aunque el hormigón autocompactante y el hormigón pesado están más que documentados en la literatura, no existen evidencias previas sobre la obtención de una mezcla de hormigón que cumpla todos los requerimientos para ser considerado un hormigón autocompactante pesado. El objetivo de este trabajo es la obtención de un hormigón autocompactante pesado a base de barita.

\section{PLAN EXPERIMENTAL}

\subsection{Materiales}

Para la fabricación del hormigón se empleó un cemento Portland puro del tipo CEM I 52,5R. La Tabla 1 muestra la composición química, mientas que la Tabla 2 recoge algunas de las propiedades físicas y mecánicas.
The slump tests consists in filling the slump cone just once, with no vibration whatsoever, and measuring the time the flow time, $T_{50}$, needed for the concrete to reach a diameter of $500 \mathrm{~mm}$ after the mould is removed. The final diameter attained, $d_{f}$, is also measured. The " $V$ " funnel test records the flow time, $T_{V}$, needed for the concrete to pass through a $V$-shaped funnel. The $L$-box contains reinforcing bars that divide a rectangular box into two compartments. A sample of fresh concrete is placed in one compartment, and the height of the concrete in the two compartments is measured after the gate between them is lifted. The blocking ratio, $C_{b L}$ is defined as the ratio between the two heights. A number of countries, Spain among them, have accepted these methods as standard procedures (12-14).

Several tests have been proposed to determine resistance to segregation. Most are based on the characterization of the coarse aggregate slump in fresh concrete columns (15-19). Unfortunately, findings have not been sufficiently repeatable or reproducible to date to advocate standardization of these methods (15).

Although self-compacting and heavyweight concrete are profusely documented in the literature, no evidence has yet been forthcoming on a concrete mix that meets all the requirements to be considered a heavyweight SCC. The purpose of the present study was to produce a barite-based, heavyweight, self-compacting concrete.

\section{EXPERIMENTAL}

\subsection{Materials}

The concrete was prepared with pure CEM I 52,5R Portland cement. Table 1 gives the chemical composition, while its most relevant physical and chemical properties are listed in Table 2.

Tabla 1 / Table 1

Dosificación del hormigón colocado y de partida (*SSS: Superficie Seca Saturada).

Doping of inicial concrete and of cast concrete (*SSD: Saturated Surface- Dry).

\begin{tabular}{|c|c|}
\hline Constituyente / Constituent & Proporción en peso (\%) / Wt (\%) \\
\hline $\mathrm{MgO}$ & 2.82 \\
\hline $\mathrm{CaO}$ libre / Free $\mathrm{CaO}$ & 1.45 \\
\hline $\mathrm{C}_{3} \mathrm{~S}$ & 67.35 \\
\hline $\mathrm{C}_{2} \mathrm{~S}$ & 8.71 \\
\hline $\mathrm{C}_{4} \mathrm{AF}$ & 8.03 \\
\hline $\mathrm{C}_{3} \mathrm{~A}$ & 7.42 \\
\hline $\mathrm{CaO} / \mathrm{SiO}_{2}$ & 3.14 \\
\hline Pérdida al fuego / Loss on ignition & 0.72 \\
\hline
\end{tabular}


Tabla 2 / Table 2

Propiedades físicas y mecánicas del cemento Portland CEM I 52,5R empleado. Physical and mechanical properties of CEM I 52,5R Portland cement.

\begin{tabular}{|c|c|c|c|c|}
\hline \multicolumn{2}{|c|}{$\begin{array}{l}\text { Tiempo de fraguado }(\mathrm{min}) / \\
\text { Time of setting }(\mathrm{min})\end{array}$} & \multirow{2}{*}{$\begin{array}{c}\text { Densidad }\left(\mathrm{g} / \mathrm{cm}^{3}\right) / \\
\text { Density }\left(\mathrm{g} / \mathrm{cm}^{3}\right)\end{array}$} & \multicolumn{2}{|c|}{$\begin{array}{c}\text { Resistencia a la compresión }\left(\mathrm{N} / \mathrm{mm}^{2}\right) \\
\text { Compressive strength }\left(\mathrm{N} / \mathrm{mm}^{2}\right)\end{array}$} \\
\hline Inicial / Initial & Final & & 2 días / 2 days & 28 días / 28 days \\
\hline 110 & 190 & 3.15 & 40.9 & 57.6 \\
\hline
\end{tabular}

La barita se obtuvo de la región de Almería en el sur de España. La Tabla 3 muestra su composición química. Puesto que el contenido de sulfato es menor del $90 \%$, la literatura indica que es difícil obtener hormigones con densidades superiores a los $3.400 \mathrm{~kg} / \mathrm{m}^{3}(4,5)$. Este hecho se corroboró posteriormente. El árido se suministró en una única fracción 0-20 mm. Puesto que con una sola fracción de árido era complicado controlar las proporciones de árido fino y grueso de la mezcla, se decidió separar previamente la barita mediante un tamiz de 4 $\mathrm{mm}$ para obtener así dos fracciones, una de arena y otra de grava. Ambas fracciones se caracterizaron de forma independiente. La Tabla 4 muestra la granulometría de la arena y la grava, mientras que la Tabla 5 recoge algunas de las principales propiedades físicas.

Se empleó un aditivo reductor de agua de alta actividad/superplastificante de base policarboxílica, especialmente diseñado para la fabricación de hormigones autocompactantes y disponible comercialmente. El fabricante
Barite was obtained from Almería, a province in southern Spain. Table 3 shows the chemical composition. Since the sulfate content is under $90 \%$, according to the literature the highest densities that can be attained are on the order of $3400 \mathrm{~kg} / \mathrm{m}^{3}(4,5)$. This was later corroborated. A single fraction of aggregate, 0-20 mm, was initially used. Since the proportions of fine and coarse aggregate were difficult to control with such a single fraction, the barite was previously separated with a 4- $\mathrm{mm}$ sieve to obtain the two fractions, sand and gravel. These two fractions were characterized independently. Table 4 gives the particle size distribution of the sand and gravel and Table 5 their chief physical properties.

A commercial high rate water-reducing admixture (a polycarboxylate-based superplasticizer) especially designed for self-compacting concrete was used. According to the manufacturer, this admixture is

Tabla 3 / Table 3

Composición mineralógica de la barita. Barite mineralogical composition.

\begin{tabular}{|c|c|}
\hline Constituyente / Constituent & Proporción en peso (\%) / Wt (\%) \\
\hline $\mathrm{SO}_{4}(\mathrm{Ba}+\mathrm{Sr})$ & $78-80$ \\
\hline $\mathrm{SiO}_{2}$ & $10-12$ \\
\hline $\mathrm{Fe}_{2} \mathrm{O}_{3}$ & $8-10$ \\
\hline
\end{tabular}

Tabla 4 / Table 4

Análisis granulométrico de las fracciones de barita. Sieve analysis of the barite fractions.

\begin{tabular}{|c|c|c|c|c|}
\hline $\begin{array}{c}\text { Característica / } \\
\text { Characteristic }\end{array}$ & $\begin{array}{l}\text { Método de ensayo / } \\
\text { Test method }\end{array}$ & $\begin{array}{c}\text { Tamiz }(\mathrm{mm}) / \\
\text { Sieve }(\mathrm{mm})\end{array}$ & $\begin{array}{c}\text { Árido fino / } \\
\text { Fine aggregate }\end{array}$ & $\begin{array}{c}\text { Árido grueso } \\
\text { Coarse aggregate }\end{array}$ \\
\hline \multirow{10}{*}{$\begin{array}{c}\text { Granulometría } \\
\text { (\% pasa) / } \\
\text { Grading (passing \%) }\end{array}$} & \multirow{10}{*}{ EN 933-1 } & 64 & 100 & 100 \\
\hline & & 32 & 100 & 98 \\
\hline & & 16 & 100 & 51 \\
\hline & & 8 & 100 & 4 \\
\hline & & 4 & 100 & 2 \\
\hline & & 2 & 75 & 1 \\
\hline & & 1 & 54 & 1 \\
\hline & & 0.5 & 35 & 1 \\
\hline & & 0.25 & 20 & 1 \\
\hline & & 0.125 & 8 & 1 \\
\hline $\begin{array}{l}\text { Contenido de finos (\%)/ } \\
\text { Fine content (\%) }\end{array}$ & EN 933-1 & 0.063 & 1.5 & 0.5 \\
\hline $\begin{array}{l}\text { Módulo de finura / } \\
\text { Fineness modulus }\end{array}$ & UNE 146301 & & 3.08 & 7.42 \\
\hline
\end{tabular}


Tabla 5 / Table 5

Propiedades físicas de los áridos.

Physical properties of the aggregates.

\begin{tabular}{|c|c|c|c|}
\hline $\begin{array}{c}\text { Característica / } \\
\text { Characteristic }\end{array}$ & $\begin{array}{c}\text { Método de ensayo / } \\
\text { Test method }\end{array}$ & $\begin{array}{c}\text { Árido fino / } \\
\text { Fine aggregate }\end{array}$ & $\begin{array}{c}\text { Árido grueso / } \\
\text { Coarse aggregate }\end{array}$ \\
\hline Equivalente de arena / Sand equivalent & EN 933-8 & 87.1 & \\
\hline Coeficiente de forma / Shape index & EN 933-4 & & 5.6 \\
\hline $\begin{array}{c}\text { Resistencia al desgaste / Resistance to wear } \\
\text { Micro-deval } \\
\text { Los Ángeles }\end{array}$ & $\begin{array}{c}\text { EN 1097-1 } \\
\text { EN 1097-2 }\end{array}$ & 75 & 67 \\
\hline Densidad (g/cm 3$) /$ Density $\left(\mathrm{g} / \mathrm{cm}^{3}\right)$ & EN 1097-6 & 4.12 & 3.59 \\
\hline Absorción de agua (\%) / Water absorption (\%) & EN 1097-6 & 1.43 & 3.95 \\
\hline
\end{tabular}

declaraba que el aditivo cumplía los requerimientos establecidos en la EN 934-2 (20). La Tabla 6 muestra algunas de las propiedades físico-químicas del aditivo.
European standard EN 934-2-compliant (20). Its physical-chemical properties are given in Table 6.

Tabla 6 / Table 6

Propiedades físico-químicas del aditivo.

Admixture physical and chemical properties.

\begin{tabular}{|c|c|}
\hline Característica / Characteristic & \\
\hline $\mathrm{pH}, 20^{\circ} \mathrm{C}$ & 6 \\
\hline Densidad, $20^{\circ} \mathrm{C} /$ Density, $20^{\circ} \mathrm{C}$ & $1.068 \mathrm{~g} / \mathrm{cm}^{3}$ \\
\hline Viscosidad, $20^{\circ} \mathrm{C} /$ Viscosity, $20^{\circ} \mathrm{C}$ & $<80 \mathrm{cps}$ \\
\hline Contenido en cloruros / Chloride content & $\leq 0.1 \%$ \\
\hline
\end{tabular}

\subsection{Diseño de la mezcla}

Se emplearon dos mezclas distintas. La primera mezcla se diseñó para la obtención de un hormigón pesado convencional, con asiento inferior a los $20 \mathrm{~cm}$, y se empleó para la determinación de la influencia de dosis crecientes de aditivo en la trabajabilidad. Tras observar que dosis elevadas podrían llevar a la obtención de un hormigón autocompactante, se modificó el contenido de cemento y la proporción de áridos con objeto de incrementar el volumen de pasta y asegurar así la cohesión de la mezcla.

\subsection{Programa de ensayos}

El objetivo de la etapa inicial del trabajo era evaluar la influencia de contenidos crecientes de aditivo en una mezcla estándar de hormigón pesado de barita. Las proporciones de los componentes de esta mezcla se muestran en la Tabla 7. La relación agua/cemento se fijó en 0,58, y a continuación se prepararon distintas amasadas con relaciones aditivo/cemento del 0,0\%; 0,5\%;0,6\%; 0,9\% y $1,8 \%$ en peso. Debido al alto grado de absorción de agua de los áridos de barita, la arena y la grava se saturaban previamente para evitar pérdidas de trabajabilidad. En cada amasada se determinó el asentamiento según la EN 12350-2 (21), la densidad en el estado fresco de acuerdo

\subsection{Mix design}

Two mixes were used. The first was designed to obtain a conventional heavyweight concrete with a slump of under $20 \mathrm{~cm}$ that was subsequently used to determine the effect of admixture dose on workabilty. After it was found that high doses could lead to a self-compacting concrete, the cement and aggregate were proportioned to optimize paste volume and mix bonding.

\subsection{Test programme}

The objective of the initial stage of the study was to assess the effect of admixture content on a standard barite-containing heavyweight concrete mix. The mix constituents and proportions are given in Table 7. The water/cement ratio was set at 0.58 and mixes were prepared with admixture/cement ratios of $0.0 \% ; 0.5 \%$; $0.6 \% ; 0.9 \%$ and $1.8 \%$ of cement weight. Due to the high water absorptivity of barite aggregate, the sand and gravel were first saturated to avoid a decline in workability. Slump as per European standard EN 12350-2 (21) and fresh concrete density as per EN 12350-6 (22) were determined for each mix and $15-\mathrm{cm}$ diameter, $30-\mathrm{cm}$ 
a la EN 12350-6 (22), y se fabricaron probetas cilíndricas de $15 \mathrm{~cm}$ de diámetro y $30 \mathrm{~cm}$ de altura, preparadas y conservadas en una cámara climática según la EN 123902 (23), con objeto de determinar la resistencia a la compresión de acuerdo a la EN 12390-3 (24).

Tras comprobar que el incremento en las dosis de aditivo podía conducir a la obtención de un hormigón autocompactante, se adoptó el procedimiento de diseño de mezclas de HAC propuesto por Gettu et al. (25), basado en la optimización de la pasta y del contenido de árido. El procedimiento desembocó en las proporciones mostradas en la Tabla 7. La dosis de superplastificante se fijó en el $2,0 \%$ del peso del cemento. high cylindrical specimens were prepared and stored in a climatic chamber as per EN 12390-2 (23) for compressive strength testing as specified in EN 12390-3 (24).

The Gettu et al. (25) SCC design procedure based on optimizing the proportions of paste and aggregate was adopted to further explore the possibilities of generating a self-compacting concrete by increasing the admixture dose, as noted earlier. The results of this exercise are listed in Table 7. The superplasticizer dose was set at $2.0 \%$ of the cement weight.

Tabla 7 / Table 7

Composición de las mezclas de hormigón. Composition of concrete mixes.

\begin{tabular}{|c|c|c|}
\hline $\begin{array}{c}\text { Componente / } \\
\text { Component }\end{array}$ & $\begin{array}{c}\text { Hormigón pesado convencional / } \\
\text { Standard heavyweight concrete }\end{array}$ & $\begin{array}{c}\text { Hormigón pesado autocompactante / } \\
\text { Self-compacting heavyweight concrete }\end{array}$ \\
\hline Cemento $\left(\mathrm{kg} / \mathrm{m}^{3}\right) /$ Cement $\left(\mathrm{kg} / \mathrm{m}^{3}\right)$ & 260 & 300 \\
\hline Árido fino $\left(\mathrm{kg} / \mathrm{m}^{3}\right) /$ Fine aggregate $\left(\mathrm{kg} / \mathrm{m}^{3}\right)$ & 1046 & 1583 \\
\hline Árido grueso $\left(\mathrm{kg} / \mathrm{m}^{3}\right) /$ Coarse aggregate $\left(\mathrm{kg} / \mathrm{m}^{3}\right)$ & 1615 & 1400 \\
\hline Agua $\left(\mathrm{l} / \mathrm{m}^{3}\right) /$ Water $\left(\mathrm{l} / \mathrm{m}^{3}\right)$ & 150 & 126 \\
\hline Relación agua $/$ cemento / Water $/$ cement ratio & 0.58 & 0.42 \\
\hline
\end{tabular}

Una vez preparado el hormigón, se determinó la autocompactabilidad por medio de los ensayos de escurrimiento, embudo en $\mathrm{V}$ y caja en $\mathrm{L}$. También se determinó la densidad en el estado fresco, y se fabricaron probetas cilíndricas de $15 \mathrm{~cm}$ x $30 \mathrm{~cm}$ para la determinación de la resistencia a la compresión tras 7 y 28 días de curado en cámara de acuerdo a la EN 12390-2 (22). Sin embargo, debido a las peculiares características del HAC, el hormigón no se compactó ni durante la determinación de la densidad ni durante el proceso de fabricación de las probetas. Todos los moldes se llenaron en un único vertido.

Debido a la alta densidad de los áridos, la segregación constituye un aspecto importante a estudiar. Puesto que, como se mencionó previamente, no existen métodos de ensayo normalizados, se empleó una adaptación del método de la columna, tanto en estado fresco como en endurecido. Se moldearon dos columnas cilíndricas de hormigón de $15 \mathrm{~cm}$ de diámetro y $70 \mathrm{~cm}$ de altura. Los moldes se llenaron de una sola vez, por la cara cilíndrica superior, sin emplear ningún medio de compactación. Durante las primeras horas, ambas columnas se dejaron reposar en posición vertical. Transcurridas tres horas tras la fabricación, se tumbó uno de los moldes, se procedió al desmoldeo, y se cortó el hormigón en tres porciones con la geometría mostrada en la Figura 1. El hormigón aún no había endurecido, pero poseía la consistencia suficiente como para no disgregarse por la acción de su propio peso. La parte superior e inferior se colocaron en un tamiz de $4 \mathrm{~mm}$, y se procedió
Once the concrete was prepared, its self-compactability was determined with the slump, "V" funnel and L-box flowability tests. Fresh density was likewise found and 15 x 30-cm cylindrical specimens were moulded and cured in a climatic chamber as specified in EN 12390-2 (22) to conduct seven- and 28-day compressive tests. Due to the peculiar characteristics of SCC, however, the concrete failed to consolidate during the density trials or during specimen manufacture. All the moulds were filled in a single lift.

Segregation was an important issue, in light of the high density of the aggregate. In the absence of standardized test methods, as mentioned above, an adaptation of the column method was used for both the fresh and hardened material. Two $15-\mathrm{cm}$ diameter, $70-\mathrm{cm}$ high cylindrical moulds were filled with a single lift of concrete from the top. Compaction was not assisted in any way. The two columns were set in a vertical position for the first few hours. Three hours after moulding, one of the specimens was laid on its side and demoulded and the concrete was cut into three portions as shown in Figure 1. The concrete had not yet hardened but was sufficiently consistent so as not to disaggregate under its own weight. The top and bottom sections were each placed in 4- $\mathrm{mm}$ sieves and the mortar was washed. The coarse aggregate retained in each sieve was 


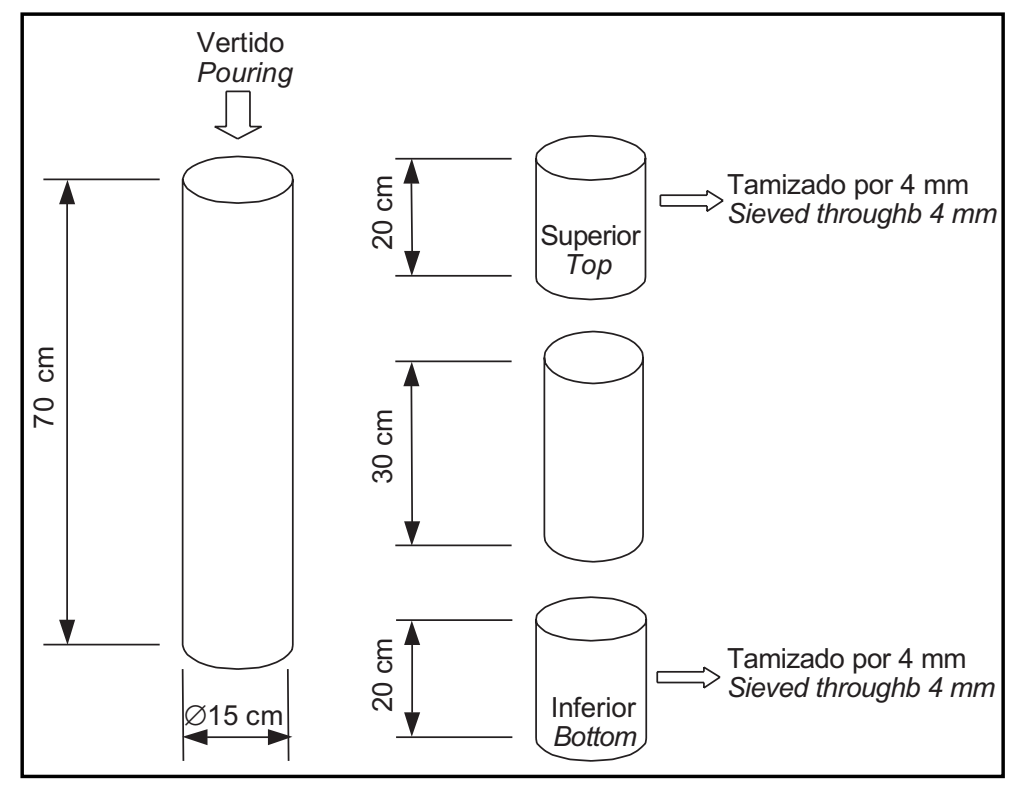

Figura 1. Muestras cortadas a partir de una columna de $15 \mathrm{~cm} \times 70 \mathrm{~cm}$ para la evaluación de la segregación en el estado fresco. Figure 1. Test samples cut from a $15 \mathrm{~cm} \times 70 \mathrm{~cm}$ column for evaluation of segregation of concrete in the fresh state.

a lavar el mortero. El árido grueso retenido se secó en una estufa a $50{ }^{\circ} \mathrm{C} \pm 2{ }^{\circ} \mathrm{C}$ hasta peso constante, y se registró la masa de árido grueso en ambos extremos.

La segunda columna de hormigón se curó en una cámara climática a $20^{\circ} \mathrm{C} \pm 2{ }^{\circ} \mathrm{C}$ y HR $>95 \%$ durante 28 días. Tras el curado, la probeta se cortó en muestras, tal como indica la Figura 2. Con objeto de redistribuir la humedad, las dried to a constant weight in an oven at $50^{\circ} \mathrm{C} \pm 2{ }^{\circ} \mathrm{C}$ and the mass recorded.

The second concrete column was cured in a climatic chamber $r$ for 28 days at $20^{\circ} \mathrm{C} \pm 2{ }^{\circ} \mathrm{C}$ and $\mathrm{RH}>95 \%$. After curing, the specimen was cut into samples as shown in Figure 2. Samples Ia, IIa and IIIa were

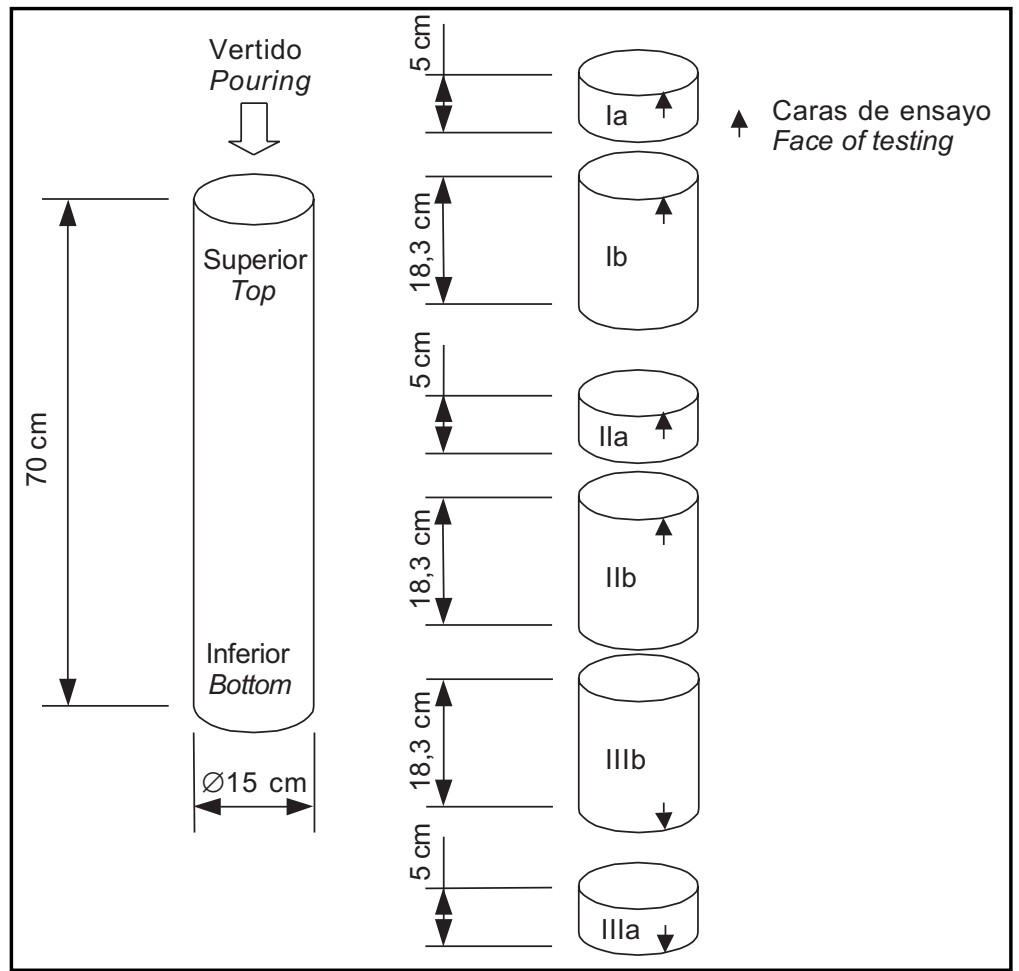

Figura 2. Muestras cortadas a partir de una columna de $15 \mathrm{~cm} \times 70 \mathrm{~cm}$ para la evaluación de la segregación en el estado endurecido. Figure 2. Test samples cut from a $15 \mathrm{~cm}$ x $70 \mathrm{~cm}$ column for evaluation of segregation of concrete in the hardened state. 
muestras Ia, IIa y IIIa se acondicionaron durante 4 días en una estufa a $50{ }^{\circ} \mathrm{C} \pm 2^{\circ} \mathrm{C}$. Tras el secado, las muestras se sellaron con un film de polietileno, y de nuevo se introdujeron en la estufa a $50^{\circ} \mathrm{C} \pm 2{ }^{\circ} \mathrm{C}$ durante tres días más. Transcurrido ese tiempo, las muestras se acondicionaron durante 21 días más en una cámara climática a $20{ }^{\circ} \mathrm{C} \pm 2$ ${ }^{\circ} \mathrm{C}$ y humedad relativa entre el $65 \%$ y el $75 \%$. Por último, se determinó la absorción de agua por capilaridad, basándose en el método propuesto por RILEM (26). Según este método, la preparación de las muestras se hace a $50^{\circ} \mathrm{C}$ de acuerdo al procedimiento propuesto por Parrott (27). Las muestras Ib, IIb y IIIb se ensayaron tras 28 días de curado estándar para determinar la profundidad de penetración del agua bajo presión según la norma EN 12390-8 (28).

Finalmente, con objeto de tener una impresión visual de la distribución del árido en el hormigón endurecido, se moldearon tres probetas cilíndricas de $10 \mathrm{~cm} \times 20 \mathrm{~cm}$, realizando el vertido de una sola vez y sin compactación. Se conservaron durante 28 días en las condiciones estándar, y posteriormente se cortaron a lo largo de su plano principal para observación.

\section{RESULTADOS Y DISCUSIÓN}

La primera etapa de la investigación estudió la influencia de la dosis de superplastificante en una mezcla de hormigón pesado convencional (Tabla 7). La Tabla 8 muestra los resultados obtenidos. La densidad media de todas las amasadas fue de $3.290 \mathrm{~kg} / \mathrm{m}^{3}$, y la resistencia media a la compresión a los 28 días fue $26,0 \mathrm{~N} / \mathrm{mm}^{2}$, sin apenas diferencias entre las distintas amasadas puesto que la relación agua/cemento era la misma en todas las mezclas. La mezcla sin aditivo resultó en un asentamiento en el rango descrito por Topcu (5). Al ir incrementando la dosis de aditivo, el asentamiento creció exponencialmente (Figura 3). Para una dosis del $1,8 \%$ en peso del cemento ya no se pudo registrar el asentamiento, puesto que la masa de hormigón se extendió completamente sobre la bandeja de ensayo, tal como hace un HAC (Figura 4). Por tanto, en ese punto se decidió tratar de obtener un hormigón autocompactante pesado. Puesto que para esa última dosis de aditivo se observó cierta exudación, se adoptó el procedimiento de diseño mencionado previamente, con objeto de obtener una mezcla más estable. conditioned in an oven for four days at $50^{\circ} \mathrm{C} \pm 2{ }^{\circ} \mathrm{C}$ to redistribute the moisture. Once dry, the samples were sealed with polyethylene film and returned to the oven for three more days at $50^{\circ} \mathrm{C} \pm 2{ }^{\circ} \mathrm{C}$. The samples were subsequently conditioned for a further 21 days in a climatic chamber at $20^{\circ} \mathrm{C} \pm 2^{\circ} \mathrm{C}$ and a relative humidity of from 65 to $75 \%$. Lastly, capillary water uptake was determined using the RILEM method (26), in which samples are prepared at $50^{\circ} \mathrm{C}$ further to the Parrott procedure (27). Samples Ib, IIb and IIIb were tested after 28 days of standard curing to determine the depth of penetration of water under pressure, as per standard EN 12390-8 (28).

Finally, three $10 \times 20-\mathrm{cm}$ cylindrical specimens were moulded in a single lift with unassisted compaction to visualize the aggregate distribution in the hardened concrete. These specimens were stored for 28 days under standard conditions and subsequently split along their long plane for observation.

\section{RESULTS AND DISCUSSION}

The first stage of the study explored the effect of superplasticizer dose on a mix of conventional heavyweight concrete (Table 7). The results are given in Table 8. The mean density of al I the mixes was 3290 $\mathrm{kg} / \mathrm{m}^{3}$, and the mean 28-day compressive strength was $26.0 \mathrm{~N} / \mathrm{mm}^{2}$. The dispersion among the mixes was narrow because the water/cement ratio was the same in all. The mix containing no admixture had a slump in the range described by Topcu (5). Slump grew exponentially with rising admixture dosage (Figure 3) For a dose of $1.8 \%$ by cement weight, slump could not be recorded, because the concrete spread completely across the test tray, as SCCS are observed to do (Figure 4) That was consequently the dose used to attempt to obtain a heavyweight self-compacting concrete. Since a certain amount of bleeding was observed for this dose, the design procedure mentioned above was adopted to obtain a more stable mix.

Tabla 8 / Table 8

Influencia de la dosis de superplastificante. Superplasticizer dosage influence.

\begin{tabular}{|c|c|c|c|}
\hline $\begin{array}{c}\text { Dosis aditivo / cemento (\% peso) / } \\
\text { Superplasticizer / cement dosage (wt. \%) }\end{array}$ & $\begin{array}{c}\text { Asiento (cm) / } \\
\text { Slump (cm) }\end{array}$ & $\begin{array}{c}\text { Densidad }\left(\mathbf{g} / \mathbf{c m}^{3}\right) / \\
\text { Density }\left(\mathbf{g} / \mathbf{c m}^{3}\right)\end{array}$ & $\begin{array}{c}\text { Resistencia a la compresión a 28 días }\left(\mathbf{N} / \mathbf{m m}^{2}\right) \text { / } \\
\text { 28-days compressive strength }\left(\mathbf{N} / \mathbf{m m}^{2}\right)\end{array}$ \\
\hline $0.0 \%$ & 3.5 & 3.26 & 25.7 \\
\hline $0.5 \%$ & 8.5 & 3.29 & 25.1 \\
\hline $0.6 \%$ & 9 & 3.30 & 26.2 \\
\hline $0.9 \%$ & 17 & 3.28 & 25.8 \\
\hline $1.8 \%$ & $>20$ & 3.30 & 27.1 \\
\hline
\end{tabular}




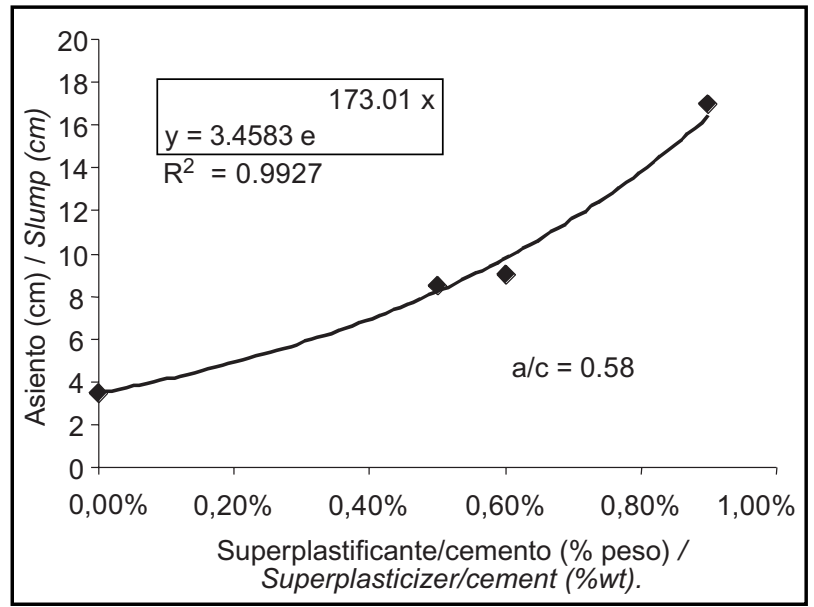

Figura 3. Asiento frente a dosis de superplastificante. Figure 3. Slump vs. superplasticizer dosage.
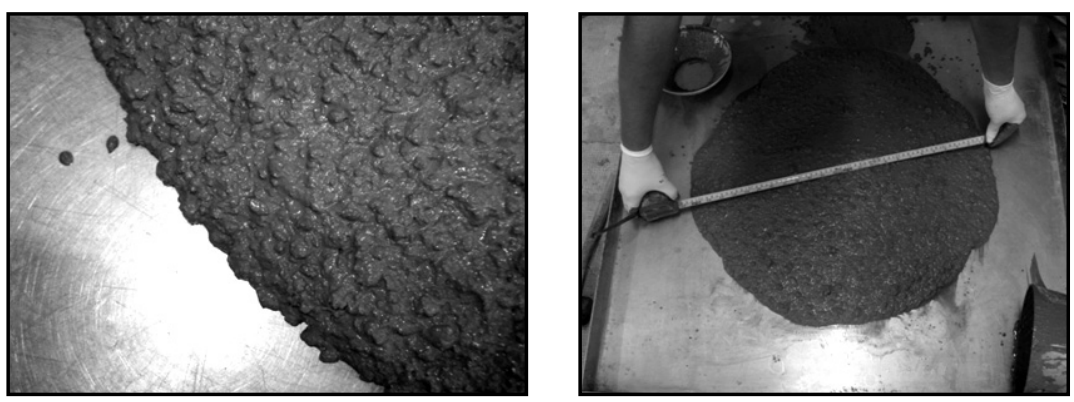

Figura 4. Aspecto del frente de avance (izda.) en el ensayo de escurrimiento (dcha.). Figure 4. Visual appearance of the flow front (left) in the slump flow test (right).

La nueva mezcla obtenida tras el proceso de diseño (Tabla 7) fue fabricada y ensayada. La densidad en el estado fresco fue de $3.300 \mathrm{~kg} / \mathrm{m}^{3}$, muy similar a la de la mezcla anterior. La Tabla 9 muestra los resultados obtenidos en los ensayos más comunes de autocompactabilidad. La Instrucción de Hormigón Estructural EHE española (29), publicada en 2008, establece que los requerimientos para un $\mathrm{HAC}$ son $550 \mathrm{~mm} \leq \mathrm{d}_{\mathrm{f}} \leq 850 \mathrm{~mm}$ y $T_{50} \leq 8$ s. Para el ensayo con el embudo en $V$ se requiere que $4 \mathrm{~s} \leq \mathrm{T}_{\mathrm{V}} \leq 20 \mathrm{~s}$. En cuanto al coeficiente de bloqueo, la EHE demanda que $0,75 \leq \mathrm{C}_{\mathrm{bL}} \leq 1,0$. Por tanto, todos los requerimientos se cumplieron. En ninguno de los ensayos anteriores se observaron muestras de segregación o exudación (Figura 4). La apariencia del hormigón era muy buena, muy fácil de manejar y verter.
The new mix resulting from the design process (Table 7) was manufactured and tested. The fresh density, at $3.300 \mathrm{~kg} / \mathrm{m}^{3}$, was very similar to the value for the previous mix. Table 9 gives the values for the most common self-compacting indicators. According to the Spanish Structural Concrete Code, EHE (29), approved in 2008, SCCs must meet the following requirements: $550 \mathrm{~mm} \leq d_{f} \leq 850 \mathrm{~mm}$ and $T_{50} \leq 8 \mathrm{~s}$. For the " $V$ " funnel test, it requires $4 s \leq T_{V} \leq 20 \mathrm{~s}$. This new code calls for a blocking ratio of $0.75 \leq C_{b L} \leq 1.0$. As Table 9 shows, the new concrete met all these requirements. No segregation or bleeding was observed in any of the above tests (Figure 4). The concrete exhibited no visual flaws and it was readily workable and easy to pour. Nor were there any surface flaws worth

Tabla 9 / Table 9

Ensayos de autocompactabilidad.

Self-compactability tests.

\begin{tabular}{|c|c|c|}
\hline $\begin{array}{c}\text { Característica / } \\
\text { Characteristic }\end{array}$ & $\begin{array}{c}\text { Método de ensayo / } \\
\text { Test method }\end{array}$ & $\begin{array}{c}\text { Resultado / } \\
\text { Result }\end{array}$ \\
\hline Escurrimiento, $\mathrm{d}_{\mathrm{f}}(\mathrm{mm}) /$ Slump, $d_{f}(\mathrm{~mm})$ & Escurrimiento (UNE 83361) / Slump flow (UNE 83361) & 630 \\
\hline Tiempo de flujo, $T_{50}(\mathrm{~s}) /$ Flow time, $T_{50}(\mathrm{~mm})$ & Escurrimiento (UNE 83361) / Slump flow (UNE 83361) & 3 \\
\hline Tiempo de flujo, $\mathrm{T}_{\mathrm{v}}(\mathrm{s}) /$ Flow time, $T_{v}(\mathrm{~s})$ & Embudo en V (UNE 83364) / V-funnel (UNE 83364) & 4 \\
\hline Coeficiente de bloqueo, $\mathrm{C}_{\mathrm{bL}} /$ Blocking ratio, $C_{b L}$ & Caja en L (UNE 83363) / L-box (UNE 83363) & 0.75 \\
\hline
\end{tabular}


El aspecto superficial de las columnas de hormigón de 15 $\mathrm{cm} \times 70 \mathrm{~cm}$ tras el desmolde, que habían sido llenadas de una sola vez, era excelente, sin ningún defecto reseñable en su superficie (Figura 5). mentioning on the $15 \times 70-\mathrm{cm}$ concrete columns (Figure 5).

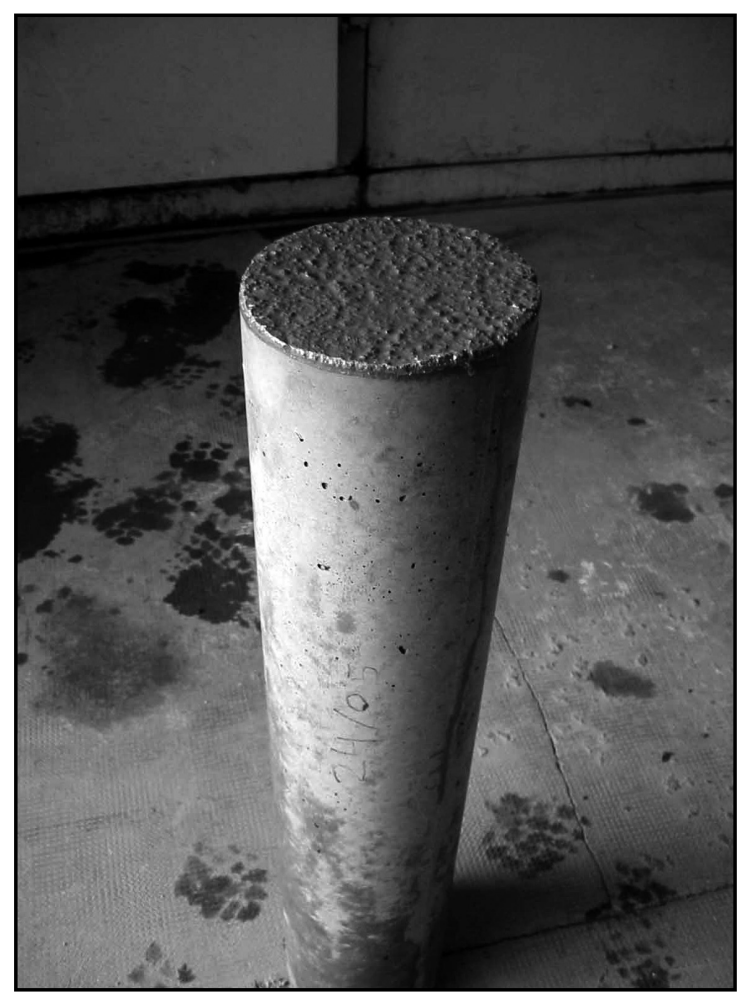

Figura 5. Aspecto de la columna de $15 \mathrm{~cm} \times 70 \mathrm{~cm}$ de hormigón pesado autocompactante tras el desmolde. Figure $5.15 \mathrm{~cm} \times 70 \mathrm{~cm}$ column aspect of self-compacting heavyweight concrete after demolding.

En cuanto a la posible segregación del hormigón, la impresión visual obtenida a partir de las probetas de 10 $\mathrm{cm} \times 20 \mathrm{~cm}$ cortadas (Figura 6) fue muy buena. Esta aparente buena homogeneidad se confirmó con los resultados de los diferentes ensayos de segregación. La Tabla 10 muestra la masa de árido grueso obtenida por tamizado en fresco de los extremos superior e inferior de
No segregation was observed in the split $10 \times 20-\mathrm{cm}$ specimens (Figure 6). This apparent homogeneity was confirmed by the segregation tests conducted. Table 10 shows the mass of coarse aggregate obtained from the top and bottom sections of the fresh concrete column when they were sieved three hours after moulding. The mass was practically the same in the two samples.

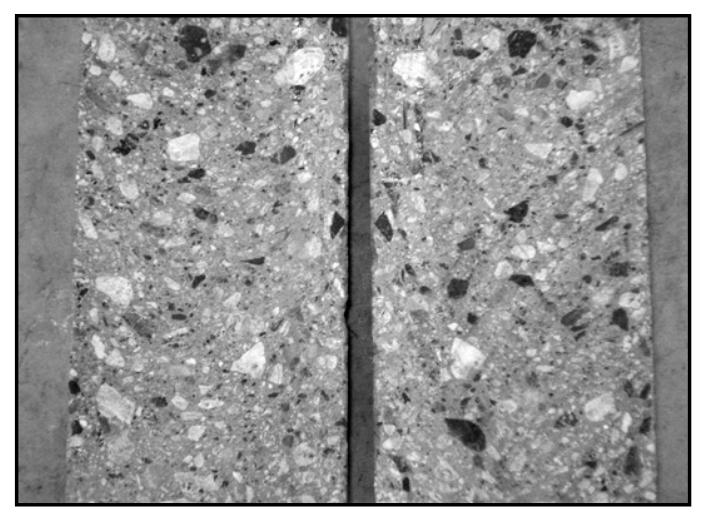

Figura 6. Aspecto de una probeta cortada de $10 \mathrm{~cm} \times 20 \mathrm{~cm}$, hormigonado de una vez y sin compactación. Figure 6. Visual appearance of a sawed $10 \mathrm{~cm}$ x $20 \mathrm{~cm}$ cylinder, cast in a single pouring without compaction aids. 
Tabla 10 / Table 10

Resultados de segregación en el estado fresco. Segregation test results in the fresh state.

\begin{tabular}{|c|c|c|}
\hline Muestra / Sample & $\begin{array}{c}\text { Masa de árido retenida en el tamiz de } \mathbf{4} \mathbf{~ m m ~ ( g ) ~ / ~} \\
\text { Aggregate sieved through } \mathbf{4 ~ m m ~ m a s s ~}(\mathrm{g})\end{array}$ & $\begin{array}{c}\text { Relación de árido grueso entre el extremo superior } \\
\text { y el inferior / Top/bottom coarse aggregate ratio }\end{array}$ \\
\hline Extremo superior / Top & 3061.5 & \\
\hline Extremo inferior/ Bottom & 3139.6 & 0.98 \\
\hline
\end{tabular}

la columna, tres horas después de la fabricación. La masa era prácticamente la misma en ambas muestras. Por tanto, se puede concluir que las partículas más pesadas no tendieron a desplazarse hacia el fondo por la acción de su peso durante las tres horas que el hormigón se dejó reposar, lo que indica que la viscosidad de la mezcla era adecuada para sostener las partículas más gruesas de barita.

La Tabla 11 muestra los resultados del ensayo de penetración al agua bajo presión. Los perfiles de penetración de agua fueron muy parecidos en las muestras superior, media e inferior de la columna. La Tabla 12 recoge los resultados de agua absorbida por capilaridad y velocidad de absorción tras 3 y 24 horas, obtenidos a partir de los datos recogidos en la Figura 7. Los valores obtenidos fueron prácticamente idénticos en las muestras superior y media, y en la parte inferior se registró una velocidad de absorción un $25 \%$ inferior a la del resto de la columna. En cualquier caso, en ambos ensayos realizados sobre hormigón endurecido, los resultados fueron lo suficientemente buenos como para considerar que el hormigón no había experimentado segregación.

Tabla 11 / Table 11

Profundidad de penetración del agua bajo presión en muestras de los extremos superior, medio e inferior de una columna endurecida de $15 \mathrm{~cm} \times 70 \mathrm{~cm}$.

Depth of penetration of water under pressure tested in the top, middle and bottom samples obtained from a hardened $15 \mathrm{~cm} \times 70 \mathrm{~cm}$ column.

\begin{tabular}{|c|c|c|}
\hline Muestra / Sample & $\begin{array}{c}\text { Profundidad máxima de penetración (mm) / } \\
\text { Maximum penetration depth ( } \mathbf{m m})\end{array}$ & $\begin{array}{c}\text { Profundidad de media de penetración (mm) / } \\
\text { Average penetration depth (mm) }\end{array}$ \\
\hline Ib (Superior) / Ib (Top) & 25 & 14 \\
\hline IIb (Medio) / IIb (Middle) & 23 & 11 \\
\hline IIIb (Inferior) / IIIb (Bottom) & 25 & 13 \\
\hline
\end{tabular}

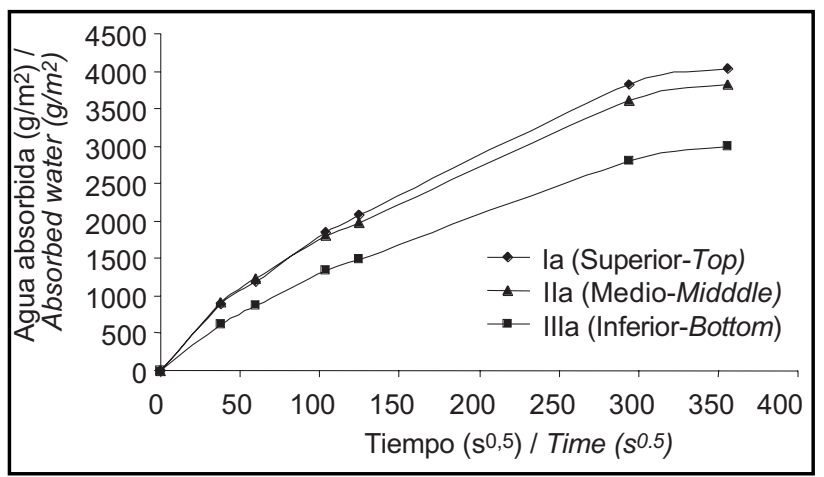

Figura 7. Absorción de agua por capilaridad en muestras de la parte superior, media e inferior de una columna de $15 \mathrm{~cm} \times 70 \mathrm{~cm}$. Figure 7. Water absorption by capillarity in top, middle and bottom samples obtained from a hardened $15 \mathrm{~cm} x 70 \mathrm{~cm}$ column. 
Tabla 12 / Table 12

Agua absorbida por capilaridad y velocidad de absorción ensayada en muestras de los extremos superior, medio e inferior de una columna endurecida de $15 \mathrm{~cm} \times 70 \mathrm{~cm}$.

Absorbed water by capillarity and absorption rate tested in the top, middle and bottom samples obtained from a hardened $15 \mathrm{~cm} \times 70 \mathrm{~cm}$ column.

\begin{tabular}{|c|c|c|}
\hline Muestra / Sample & $\begin{array}{l}\text { Agua absorbida }\left(\mathrm{g} / \mathrm{m}^{2}\right) / \\
\text { Absorbed water }\left(\mathrm{g} / \mathrm{m}^{2}\right)\end{array}$ & $\begin{array}{c}\text { Velocidad de absorción }\left(\mathrm{g} / \mathrm{m}^{2} / \mathrm{s}^{0.5}\right) / \\
\text { Absorption rate }\left(\mathrm{g} / \mathrm{m}^{2} / \mathrm{s}^{0.5}\right)\end{array}$ \\
\hline \multicolumn{3}{|l|}{ Ia (Superior) / Ia (Top) } \\
\hline 3 horas / 3 hours & 1844.9 & 17.8 \\
\hline 24 horas / 24 hours & 3813.2 & 13.0 \\
\hline \multicolumn{3}{|l|}{ IIa (Medio) / IIa (Middle) } \\
\hline 3 horas / 3 hours & 1805.2 & 17.4 \\
\hline 24 horas / 24 hours & 3604.7 & 12.3 \\
\hline \multicolumn{3}{|c|}{ IIIa (Inferior) / IIIa (Bottom) } \\
\hline 3 horas / 3 hours & 1335.5 & 12.9 \\
\hline 24 horas / 24 hours & 2795.5 & 9.5 \\
\hline
\end{tabular}

Por ultimo, se determinó la resistencia a la compresión. Los resultados se muestran en la Tabla 13 , sin que se observara ningún efecto destacable.
Lastly, the specimens were tested for compressive strength. As the findings listed in Table 13 show, no significant effects were observed.

Tabla 13 / Table 13

Resistencia a la compresión a 7 y 28 días.

Compressive strength at 7 and 28 days.

\begin{tabular}{|c|c|}
\hline Edad / Age & $\begin{array}{c}\text { Resistencia a la compresión }\left(\mathbf{N} / \mathbf{m m}^{2}\right) \\
\text { Compressive strength }\left(\mathbf{N} / \mathbf{m m}^{2}\right)\end{array}$ \\
\hline 7 días / 7 days & 24 \\
\hline 28 días / 28 days & 31 \\
\hline
\end{tabular}

\section{CONCLUSIONES}

Los resultados de este trabajo muestran que la incorporación de un superplastificante a base de policarboxilatos a una mezcla de hormigón de alta densidad de barita incrementa la trabajabilidad del hormigón de manera exponencial, consiguiéndose asientos superiores a los 20 $\mathrm{cm}$ para dosis de superplastificante en torno al 1,8\%, hasta el punto de que es posible diseñar una mezcla con propiedades de autocompactabilidad. En este estudio se consiguió fabricar un hormigón autocompactante con árido de barita, con una densidad de $3.300 \mathrm{~kg} / \mathrm{m}^{3}$, que fue posteriormente caracterizado con los métodos de ensayo más habituales para este tipo de hormigón. La capacidad de fluir y la habilidad de paso a través de armaduras se midieron con el ensayo de escurrimiento, el embudo en V y la caja en L. El escurrimiento obtenido, $d_{f}$, fue de $630 \mathrm{~mm}$, el tiempo de paso por el embudo en $V, T_{V}$, de $4 \mathrm{~s}$, y el coeficiente de bloqueo, $C_{b L}$, de 0,75 , siendo los resultados acordes con lo exigido a un hormigón autocompactante. La resistencia a la segregación se midió mediante diferentes ensayos realizados sobre muestras obtenidas a partir de columnas de hormigón de $15 \mathrm{~cm}$ de diámetro y $70 \mathrm{~cm}$ de altura. En uno de ellos, realizado sobre la columna de hormigón en

\section{CONCLUSIONS}

According to the above findings, the inclusion of a polycarboxylate-based superplasticizer in a high density barite concrete mix heightened concrete workability exponentially, with slumps greater than $20 \mathrm{~cm}$ with a dose of $1.8 \%$, i.e., at which a self-compacting mix can be designed. In this study, self-compacting concrete was prepared with barite aggregate and a density of 3300 $\mathrm{kg} / \mathrm{m}^{3}$, and subsequently characterized with the usual test methods for this type of concrete. Flowability and passing ability around reinforcement bars were measured with the slump, "V" funnel and L-box tests. The slump obtained, $d_{f}$, was $630 \mathrm{~mm}$, the " $V$ " funnel flow time, $T_{V}$, was four seconds, and the blocking ratio, $C_{b L}$, was 0.75. All these results conform to standard requirements for self-compacting concrete. Resistance to segregation was measured with tests conducted on samples obtained from concrete columns $15 \mathrm{~cm}$ in diameter and $70 \mathrm{~cm}$ high. In one such test, conducted on fresh concrete, the top and bottom were washed through a 4-mm sieve and the material retained was subsequently weighed. The ratio between the coarse aggregate in the top and bottom was 0.98. Tests were conducted on a column of hardened concrete to 
estado fresco, se tamizaron los extremos superior e inferior de la misma a través de un tamiz de $4 \mathrm{~mm}$, pesándose a continuación el material obtenido. La relación entre el árido grueso de la parte superior y la inferior era de 0,98 . Sobre otra columna de hormigón, ya endurecido, se llevaron a cabo ensayos de absorción de agua por capilaridad y de penetración de agua bajo presión. La penetración de agua es similar en todas las porciones de la columna, mientras que la muestra obtenida de la parte inferior muestra una absorción un $25 \%$ inferior a la de las porciones obtenidas de la parte media y superior. En cualquier caso, puede considerarse que los resultados no muestran evidencias de segregación. La apariencia visual de las columnas también fue muy buena.

Un aspecto a destacar de manera especial es el hecho de que, aunque la mayoría de las guías de diseño de hormigones autocompactantes $(6,9)$ sugieren que las mezclas de HAC deben estar compuestas por entre 160 y $240 \mathrm{l} / \mathrm{m}^{3}$ de finos (material por debajo de 0,125 $\mathrm{mm})$, la mezcla obtenida en este trabajo tenía únicamente $130 \mathrm{l} / \mathrm{m}^{3}$. Por tanto, aunque pudiera pensarse que un hormigón autocompactante pesado, por la mayor densidad de las partículas gruesas, debería ser más susceptible a la segregación y, por tanto, debería incrementarse el contenido de finos con objeto de incrementar la viscosidad de la mezcla y mantener las partículas gruesas en suspensión, este trabajo demuestra que, bien al contrario, es posible obtener un hormigón autocompactante pesado con un contenido de pasta inferior al habitual de los hormigones autocompactantes convencionales. determine capillary water uptake and depth of penetration of water under pressure. Water penetration proved to be similar in all sections of the column, while absorption at the bottom was $25 \%$ lower than in the other portions. In any event, these findings evinced no segregation. No visual flaws were observed in these columns.

One finding of particular interest was that while most self-compacting design guides $(6,9)$ suggest that SCC mixes should contain from 160 to $240 \mathrm{l} / \mathrm{m}^{3}$ of fines (material under $0.125 \mathrm{~mm}$ ), the mix obtained in this study contained only $130 \mathrm{l} / \mathrm{m}^{3}$. A heavyweight, selfcompacting concrete might be thought to be more liable to segregate due to the higher density of its coarse particles, a circumstance that would consequently call for increasing the fines content to raise mix viscosity and hold the coarse particles in suspension. This study showed, however, that heavyweight, self-compacting concrete can be obtained with a paste content lower than usually found in conventional self-compacting concretes.

\section{BIBLIOGRAFÍA / BIBLIOGRAPHY}

(1) ACI Committee 304: ACI Technical Document 304.3R-96, Heavyweight Concrete: Measuring, Mixing, Transporting, and Placing, American Concrete Institute, Farmington Hills (MI), USA (1996).

(2) Pihlajavaara, S. E.: ACI Special Publication 34, Preliminary Recommendation for Design, Making and Control of Radiation-Shielding Concrete Structures, American Concrete Institute, Farmington Hills (MI), USA (1972).

(3) Miller, E.: "High-density and radiation-shielding concrete and grout", en J. Newman, B. S. Choo (eds.): Advanced Concrete Technology-Processes, Elsevier, Oxford, UK (2003), pp. 5/1-5/15.

(4) Kilincarslan, S.; Akkurt, I.; Basyigit, C.: "The effect of barite rate on some physical and mechanical properties of concrete", Mater. Sci. Eng. A, vol. 424 (2006), pp. 83-86. doi:10.1016/j.msea.2006.02.033

(5) Topcu, I. B.: "Properties of heavyweight concrete produced with barite", Cem. Concrete Res., vol. 33 (2003), pp. 815-822. doi:10.1016/S0008-8846(02)01063-3

(6) Okamura, H.; Ozawa, K.: ACI Special Publication 159, Self-Compactable High-Performance Concrete in Japan, American Concrete Institute, Farmington Hills (MI), USA (1996).

(7) Khayat, K. H.: "Workability, testing and performance of self-consolidating concrete", ACI Mater. J., vol. 96 (1999), pp. 346-353.

(8) Gallo, E.; Revuelta, D.: "Verificación de las propiedades reológicas del hormigón autocompactable", Bol. Soc. Esp. Ceram. V, vol. 43, n० 2 (2004), pp. 556-559.

(9) EFNARC: Specification and Guidelines for Self-Compacting Concrete, EFNARC, Farnham, UK (2002).

(10) Domone, P.: "The slump flow test for high-workability concrete", Cem. Concr. Res., vol. 28, no 2 (1998), pp. $177-182$. doi:10.1016/S0008-8846(97)00224-X

(11) Ozawa, K.; Sakata, N.; Okamura, H.: "Evaluation of self compactability of fresh concrete using the funnel test", Proc. Japan Soc. of Civil Eng., vol. 23, no 490 (1994), pp. 71-80. 
(12) Comité Técnico de Normalización AEN/CTN 83, Norma UNE 83361: "Hormigón autocompactante. Caracterización de la fluidez. Ensayo de escurrimiento", AENOR, Madrid, España (2007).

(13) Comité Técnico de Normalización AEN/CTN 83, Norma UNE 83363: "Hormigón autocompactante. Caracterización de la fluidez en presencia de barras. Método de la caja en L", AENOR, Madrid, España (2007).

(14) Comité Técnico de Normalización AEN/CTN 83, Norma UNE 83364: "Hormigón autocompactante. Determinación del tiempo de flujo. Ensayo del embudo en V", AENOR, Madrid, España (2007).

(15) Valcuende, M. O.; Parra, C.; Jarque, J. C.: "Homogeneidad de los hormigones autocompactables", Mater. Construcc., vol. 57, no 287 (2007), pp. 37-52.

(16) Otsuki, N.; Hisada, M.; Nagataki, S.; Kamada, T.: "An experimental study on the fluidity of antiwashout underwater concrete", $A C I$ Mater. J., vol. 93 (1996), pp. 20-25.

(17) Rooney, M. J.; Bartos, P. J. M.:"Development of the settlement column segregation test for fresh self-compacting concrete", en K. Ozawa; M. Ouchi (eds.): Proc. Second Intnl. Symp. on Self-Compacting Concrete (Tokyo), COMS Engineering Corp., Kochi, Japón (2001), pp. 109-116.

(18) Greenland, A.; Cussigh, F.: Bétons auto-plaçants (recommandations provisoires), Association Française de Génie Civil, París, Francia (2000).

(19) Gomes, P. C.; Gettu, R.; Agulló, L.; Bernard, C.: "Experimental optimization of high-strength self-compacting concrete", en K. Ozawa; M. Ouchi (eds.): Proc. Second Intnl. Symp. on Self-Compacting Concrete (Tokyo), COMS Engineering Corp., Kochi, Japón (2001), pp. 377-386.

(20) Technical Committee CEN/TC 104, European Standard EN 934-2:2001: "Admixtures for concrete, mortar and grout-Part 2: Concrete admixtures-Definitions, requirements, conformity, marking and labelling", European Committee for Standardization (CEN), Bruselas, Bélgica (2001).

(21) Technical Committee CEN/TC 104, European Standard EN 12350-2:1999: "Testing fresh concrete-Part 2: Slump test", European Committee for Standardization (CEN), Bruselas, Bélgica (1999).

(22) Technical Committee CEN/TC 104, European Standard EN 12350-6:1999: "Testing fresh concrete-Part 6: Density", European Committee for Standardization (CEN), Bruselas, Bélgica (1999).

(23) Technical Committee CEN/TC 104, European Standard EN 12390-2:2000: "Testing hardened concrete-Part 2: Making and curing specimens for strength tests", European Committee for Standardization (CEN), Bruselas, Bélgica (2000).

(24) Technical Committee CEN/TC 104, European Standard EN 12390-2:2001: "Testing hardened concrete-Part 3: Compressive strength of test specimens", European Committee for Standardization (CEN), Bruselas, Bélgica (2001).

(25) Gettu, R.; Gomes, P. C.; Agulló, L.: "Hormigón autocompactante de alta resistencia: diseño de mezclas y métodos de caracterización", en Proc. del II Congreso de ACHE, Asociación Científico-Técnica del Hormigón Estructural ACHE, Madrid, España (2002), pp. 13-22.

(26) Technical Committee TC14-CPC: "CPC11.2 Absorption of water by concrete by capillarity", en RILEM Technical Recommendations for the Testing and Use of Construction Materials, E\&FN Spon, Londres, UK (1994), pp. 34-35.

(27) Parrott, L. J.: "Moisture conditioning and transport properties of test specimens", Mater. Struct., 27 (1994), pp. 460-468.

doi:10.1007/BF02473450

(28) Technical Committee CEN/TC 104, European Standard EN 12390-8:2000: "Testing hardened concrete-Part 8: Depth of penetration of water under pressure", European Committee for Standardization (CEN), Bruselas, Bélgica (2001).

(29) Comisión Permanente del Hormigón: "Anejo 17: Recomendaciones para el uso de hormigón autocompactante", en Borrador de la Instrucción de Hormigón Estructural EHE, Ministerio de Fomento, Madrid, España (2007), pp. A17.1-A17.14. 